\title{
In Vitro Thermal Effects on Embryonic Cells of Endangered Hawksbill Turtle Eretmochelys imbricata
}

\author{
Satoshi Takeshita ${ }^{*}$, Naoki Matsuda ${ }^{2}$, Seiji Kodama ${ }^{3}$, \\ Keiji Suzuki ${ }^{4}$, and Masami Watanabe ${ }^{5}$ \\ ${ }^{1}$ Center for Industry, University and Government Cooperation, Nagasaki University, \\ 1-14 Bunkyo, Nagasaki 852-8521, Japan \\ ${ }^{2}$ Center for Frontier Life Sciences, Nagasaki University, 1-12-4 Sakamoto, Nagasaki 852-8523, Japan \\ ${ }^{3}$ Graduate School of Science, Osaka Prefecture University, 1-2 Gakuen, Sakai, Osaka 599-8531, Japan \\ ${ }^{4}$ Graduate School of Biomedical Science, Nagasaki University, 1-12-4 Sakamoto, Nagasaki 852-8523, Japan \\ ${ }^{5}$ Research Reactor Institute, Kyoto University, Kumatori, Sennan-gun, Osaka 590-0494, Japan
}

\begin{abstract}
The hawksbill turtle is an ectotherm, whose sex is determined by temperature during embryonic development. This study aimed to determine whether embryonic hawksbill turtle cells respond differently to temperature than mammalian cells. Embryonic hawksbill turtle cells were established in culture, and thermal effects on these cells were investigated in vitro. Cells were maintained in Dulbecco's Modified Eagle Medium supplemented with non-essential amino acids, vitamin solution, sodium pyruvate, and $10 \%$ fetal bovine serum at $33^{\circ} \mathrm{C}$ and cell proliferation occurred at $25-33^{\circ} \mathrm{C}$. When cells were incubated at $37^{\circ} \mathrm{C}$ (the temperature of mammalian cell culture) for $24 \mathrm{~h}$, cell growth was completely inhibited. This growth inhibition was evidently recovered by changing the incubation temperature back to $33^{\circ} \mathrm{C}$. Expression of heat shock protein was found to increase with elevating culture temperature from 25 to $33^{\circ} \mathrm{C}$.
\end{abstract}

Key words: hawksbill turtle, embryonic cells, temperature sensitivity, growth inhibition, heat shock protein

\section{INTRODUCTION}

Primary reptilian cell cultures have been described by several investigators. These include various cells from the heart of the box turtle, Terrapene carolina (Clark and Karzon, 1967; Huang and Clark, 1967), the skin of the green sea turtle, Chelonia mydas (Koment and Haines, 1982), the heart and lung of the Tokai gecko, Gecko gecko, the heart, liver and kidney of the green iguana, Iguana iguana, the heart of the side-necked turtle, Podocnemis unifilis, and the spleen of the Grecian tortoise, Testudo graeca (Clark et al., 1970). Cell lines have also been established from cutaneous fibropapillomas of C. mydas (Mansell et al., 1989; Lu et al., 1999). However, embryonic cell cultures have not been established from the hawksbill sea turtle, Eretmochelys imbrica.

In 1996, the hawksbill turtle was listed as critically endangered by the International Union for the Conservation of Nature and Natural Resources and by the Convention on International Trade in Endangered Species (CITES) (Mortimer et al., 2007). Bowen et al. (2007) indicated that an effective conservation strategy would depend on understanding key aspects of hawksbill biology, including the degree of isolation among nesting colonies, migratory pathways of juveniles and adults, and the source (nesting col-

\footnotetext{
* Corresponding author. Tel. : : +81-95-819-2227;

Fax : +81-95-819-2228;

E-mail: juniper@nagasaki-u.ac.jp
}

ony) of the foraging population. Development of a cell line from this organism and studies utilizing hawksbill cells will be crucial to these efforts.

It is well known that in reptiles, including many turtles, some lizards and all crocodilians, sex determination is dependent on the incubation temperature of eggs during specific periods of embryonic development (Bull, 1980; Raynaud and Pieau, 1985; Dournon et al., 1990; Janzen and Paukstis, 1991; Pieau et al., 1994). At low incubation temperature, hatchlings are of one sex, while at high temperature they are of the opposite sex. At intermediate temperatures, hatchlings of both sexes are produced (Harry et al., 1990). In turtles, low temperature induces males (Yntema and Mrosovsky, 1980; Yntema and Mrosovsky, 1982; Standora and Spotila, 1985), while in lizards and crocodilians, females are induced (Deeming and Ferguson, 1988).

At the cellular level, the response to temperature is known to induce synthesis of a small set of highly conserved proteins called heat shock proteins (hsps). This response is universal, although some features of the response vary from one organism to another. Moreover, Marshall and Harley (2001) indicate that an interaction between hsp70, the major inducible hsp and SOX9, an important developmental transcription factor, may be significant in the process of mammalian sex determination.

The primary aim of this study was to establish hawksbill cell cultures and elucidate hawksbill cellular characteristics in response to culture temperature changes. 


\section{MATERIALS AND METHODS}

\section{Initiation of cell culture}

Eggs of $E$. imbricata were obtained with permission from the Okinawa Commemorative National Government Park, Okinawa, Japan. Whole embryos were removed from the eggs (day 42 postlay), and sections of muscle were removed from the neck, shoulder and belly regions of the embryos. All sections were placed directly into $35 \mathrm{~mm}$ plastic cell culture dishes with phosphate buffered saline (PBS) containing antibiotics (100 U penicillin $\mathrm{G} / \mathrm{ml}$ and $200 \mu \mathrm{g}$ streptomycin $/ \mathrm{ml}$ ) and left for $2 \mathrm{~h}$ at $4^{\circ} \mathrm{C}$. After two additional washes in trypsin/EDTA solution (Invitrogen Corp., Carlsbad, CA, USA), tissue sections were finely minced using sterile instruments and incubated at $30^{\circ} \mathrm{C}$ for $1 \mathrm{~h}$. The trypsin-digested mixtures were centrifuged at low speed and washed twice with Dulbecco's Modified Eagle Medium (DMEM) (Invitrogen Corp.) supplemented with non-essential amino acids, vitamin solution and $10 \mathrm{mM}$ sodium pyruvate (Invitrogen Corp.). The resulting cell pellet was seeded into $35 \mathrm{~mm}$ collagen-coated dishes in DMEM supplemented with non-essential amino acids, vitamin solution, sodium pyruvate, $10 \%$ fetal bovine serum (FBS) (Intergen Co., Purchase, NY, USA) and antibiotics. Cell cultures were incubated at $30^{\circ} \mathrm{C}$ in a $5 \% \mathrm{CO}_{2}$ humidified incubator. The medium was changed twice a week, and on reaching confluence, cells were sub-cultivated at a ratio of 1:4 with growth medium (without antibiotics).

Human embryonic cells were obtained from abdomen tissues of 7-8 week-old human embryos, as described previously (Watanabe et al., 1992). Cells were cultured in Eagle's Minimum Essential Medium supplemented with $0.2 \mathrm{mM}$ serine, $0.2 \mathrm{mM}$ aspartate, $1 \mathrm{mM}$ pyruvate, $10 \mathrm{mM}$ 2-[4-(hydroxyethyl)-1-piperazinyl] ethanesulfonic acid (HEPES), 100 units $/ \mathrm{ml}$ penicillin, $100 \mu \mathrm{g} / \mathrm{ml}$ streptomycin, and $10 \% \mathrm{FBS}$ at $37^{\circ} \mathrm{C}$ in a $5 \% \mathrm{CO}_{2}$ humidified incubator. $10^{6}$ cells were inoculated in a $75 \mathrm{~cm}^{2}$ plastic flask and subcultured every seven days.

\section{Growth studies}

Growth characteristics of the newly established embryonic hawksbill turtle cells were evaluated at selected temperatures. To determine the incubation temperature for optimal cell growth, $2 \times$ $10^{4}$ cells at passage $5-10$, were seeded in $35 \mathrm{~mm}$ tissue culture dishes and pre-incubated at $30^{\circ} \mathrm{C}$ for $24 \mathrm{~h}$, prior to further incubation at $25,27,30,33$, and $37^{\circ} \mathrm{C}$ in a $5 \% \mathrm{CO}_{2}$ humidified incubator. On days 2,4 , and 7 , cells from three dishes at each temperature were trypsinized, counted with a hemocytometer and average cell counts were calculated. Each experiment was performed in triplicate and the mean and standard error (SE) of the mean were plotted.

\section{Flow cytometric analysis}

Cell numbers in the different phases of the cell cycle at $33^{\circ} \mathrm{C}$ and $37^{\circ} \mathrm{C}$ were measured by uptake and intercalation of propidium iodide (PI) to DNA. Briefly, on reaching cell confluence, FBS concentration was reduced from $10 \%$ to $0.05 \%$ in the growth medium and cells were further incubated at $33^{\circ} \mathrm{C}$ for $24 \mathrm{~h}$ (serum starvation). After cell synchronization by serum starvation, cells were harvested by trypsin treatment and were reseeded $\left(5 \times 10^{5}\right)$ onto $90 \mathrm{~mm}$ dishes in growth medium. Cells were incubated at $33^{\circ} \mathrm{C}$ for $5 \mathrm{~h}$ and further incubated at $33^{\circ} \mathrm{C}$ or $37^{\circ} \mathrm{C}$ for $24 \mathrm{~h}$. Flow cytometric analysis was carried out using a FACScan flow cytometer (Becton Dickinson, Franklin Lakes, NJ, USA). For flow cytometry, cells were prepared at $1 \times 10^{6} / \mathrm{ml}$, washed twice with PBS and fixed in ice cold $70 \%$ ethanol for 30 min on ice before the addition of PI.

\section{Determination of hsp70 by western blotting analysis}

To detect hsp70 production, turtle cells at passage 10-15 were seeded in $90 \mathrm{~mm}$ plastic tissue culture dishes and pre-incubated at $33^{\circ} \mathrm{C}$ for $24 \mathrm{~h}$. Cells were then transferred to and maintained at either 33 or $37^{\circ} \mathrm{C}$ in a $5 \% \mathrm{CO}_{2}$ humidified incubator. Human embryonic cells were seeded into plastic cell culture flasks (T-25) and preincubated at $37^{\circ} \mathrm{C}$ for $24 \mathrm{~h}$, and then rapidly warmed in a water bath maintained at $43^{\circ} \mathrm{C}$ for $24 \mathrm{hr}$. Under these conditions, $0.1 \%$ of human embryonic cells survived.

To determine hsp70 levels at different culture temperatures, cells at passage 10-15 were seeded onto $60 \mathrm{~mm}$ tissue culture dishes and pre-incubated at $25^{\circ} \mathrm{C}$ for $24 \mathrm{~h}$. Cells were then transferred to and maintained at $25,27,30,33$ and $37^{\circ} \mathrm{C}$ in a $5 \% \mathrm{CO}_{2}$ humidified incubator.

To obtain total cell protein, cells were lysed in RIPA buffer (50 $\mathrm{mM}$ Tris- $\mathrm{HCl}$ buffer, $\mathrm{pH} 7.2,150 \mathrm{mM} \mathrm{NaCl}, 1 \% \mathrm{NP}-40,1 \%$ Sodium deoxycholate, $0.1 \% \mathrm{SDS}$ ). After freezing at $-20^{\circ} \mathrm{C}$, the cell lysate was centrifuged for $30 \mathrm{~min}$ at $18,500 \times \mathrm{g}$. The supernatant was harvested and protein content was measured using bovine serum albumin as a standard. Fifteen micrograms of protein per lane was loaded onto an SDS-polyacrylamide gel and electrophoresis (SDSPAGE) was performed using the Laemmli method (Laemmli, 1970) at $7.5 \%$ gel concentration. Proteins were transferred electrophoretically in transfer buffer $(0.1 \mathrm{M}$ Tris, $0.192 \mathrm{M}$ glycine, $20 \%$ methanol) onto polyvinyl difluoride filters. The filters were blocked overnight with $10 \%$ dried milk. In order to determine cross-reactivity, four monoclonal antibodies recognizing only heat-inducible type hsp72 proteins (W27, Oncogene Science, Inc., Cambridge, MA, USA), constitutive heat shock cognate (hsc)-73 protein (IB5, Stressgen Biotechnologies, Corp., San Diego, CA, USA), hsp72 and hsc73 proteins (N27F, Stressgen Biotechnologies, Corp., and 5A5, Affinity Bio Reagents, Inc. Golden, CO, USA ), were used as primary antibodies. To visualize bound primary antibodies, filters were incubated with biotinylated anti-mouse or rat Ig whole antibody (Amersham Japan Co. Ltd., Tokyo, Japan) and streptavidin/biotinylated alkaline phosphatase conjugate (Amersham Japan Co. Ltd.). This was followed by incubation with 5-bromo-4-chloro-3-indolylphosphate $p$-toluidine salt and nitroblue tetra -zolium chloride (Invitrogen Corp.) for color development. The amount of hsp70 was determined by densitometric analysis.

\section{Statistical analysis}

All data are expressed as mean \pm standard error. Statistical analysis for cell growth characteristics was performed using a paired Student's $t$-test. Differences were considered statistically significant when $P<0.05$.

\section{RESULTS}

\section{Cell growth characteristics}

Cell adhesion from the hawksbill turtle muscle sections to the cell culture dishes was slow. Only muscle sections removed from the neck successfully produced a confluent monolayer by 12 days. However, once initial monolayers were formed, growth became more rapid and maintenance in growth medium enabled approximately 50 subcultures to be made. Cells cryopreservation was carried out in growth medium containing 15\% FBS and $10 \%$ dimethylsulfoxide at $-196^{\circ} \mathrm{C}$.

Growth characteristics of the newly established embryonic hawksbill turtle cells were evaluated at selected temperatures. Hawksbill turtle cells showed temperaturedependent cell proliferation between 25 and $33^{\circ} \mathrm{C}$, and optimal cell growth was achieved when cells were incubated at $33^{\circ} \mathrm{C}$ (Fig. 1). At this temperature, a confluent monolayer was reached one week after seeding. The number of confluent cells per $35 \mathrm{~mm}$ tissue culture dish was approximately $2.8 \times 10^{5}$ cells. Cell proliferation significantly decreased at $22^{\circ} \mathrm{C}$ and was negligible at $19^{\circ} \mathrm{C}$ (data not shown). At $37^{\circ} \mathrm{C}$, hawksbill turtle cell growth was completely inhibited (Fig. 1). 


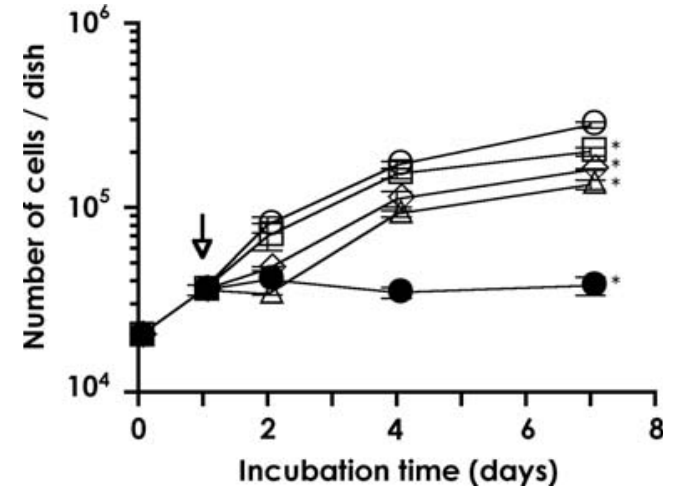

Fig. 1. Growth of hawksbill turtle cells at various incubation temperatures. Cells were plated at $2 \times 10^{4}$ cells $/ 35 \mathrm{~mm}$ culture dish in DMEM $/ 10 \% \mathrm{FBS}$ and incubated at $30^{\circ} \mathrm{C}$ for $24 \mathrm{~h}$. Cells were then incubated at $25(\triangle), 27(\diamond), 30(\square), 33(\bigcirc)$ and $37^{\circ} \mathrm{C}(\bigcirc)$ (arrow in the figure) for up to 7 days. The growth curve was determined by cell counts using a hemocytometer. For each time point the mean and standard error of the mean are plotted $(n=3)$. Each experiment was performed in triplicate. Statistical significance $(P<0.05)$ from $33^{\circ} \mathrm{C}$ is indicated by asterisks.
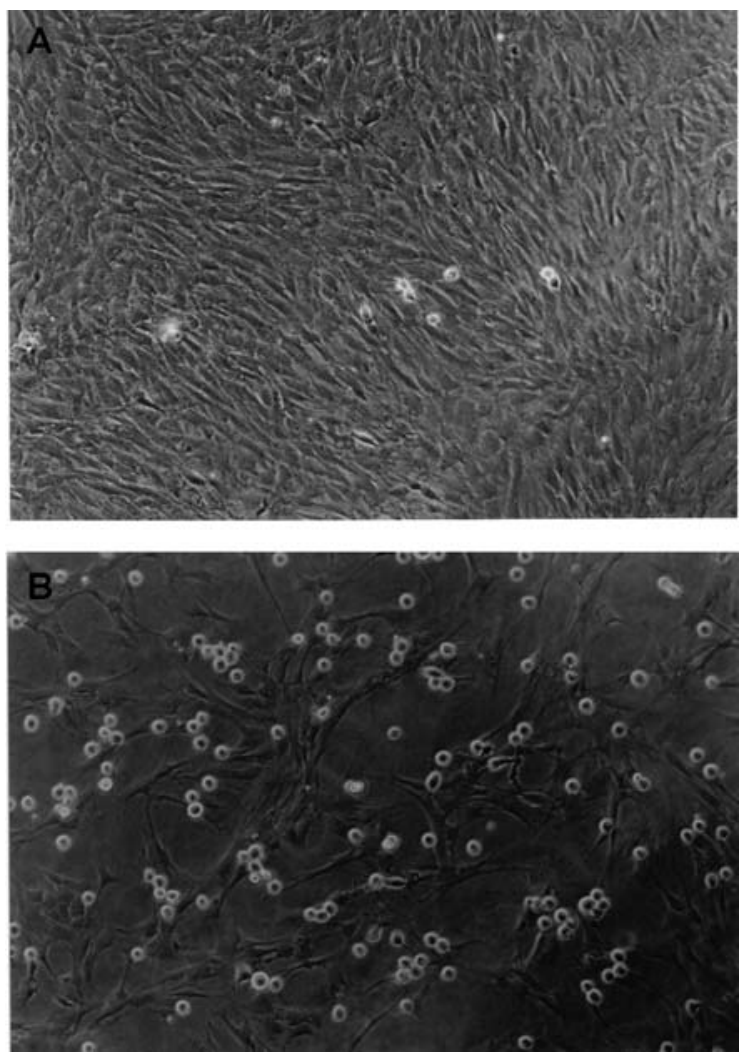

Fig. 2. Phase-contrast micrographs of cultured hawksbill turtle cells (original magnification $\times 40$ ). (A) Hawksbill turtle cell morphology during normal growth, $33^{\circ} \mathrm{C}$. (B) Change in morphology during growth inhibition, $37^{\circ} \mathrm{C}, 24 \mathrm{~h}$.

\section{Morphological change}

Cellular morphologies during optimal growth $\left(33^{\circ} \mathrm{C}\right)$ and growth inhibition $\left(37^{\circ} \mathrm{C}\right)$ states, were observed in passage 8 cell cultures. Hawksbill turtle cells exhibited fibroblastic morphology and formed monolayers at $33^{\circ} \mathrm{C}$ (Fig. 2A). When
Table 1. Effect of temperature on cell cycle progression by flow cytometric analysis after synchronization.

\begin{tabular}{cccc}
\hline Growth Phase & $\%$ Synchronized & $33^{\circ} \mathrm{C}, 24 \mathrm{~h}$ & $37^{\circ} \mathrm{C}, 24 \mathrm{~h}$ \\
\hline $\mathrm{G}_{0} / \mathrm{G}_{1}$ & $92.4 \%$ & $39.2 \%$ & $77.6 \%$ \\
$\mathrm{~S}$ & $3.6 \%$ & $46.6 \%$ & $22.1 \%$ \\
$\mathrm{G}_{2} / \mathrm{M}$ & $4.0 \%$ & $14.2 \%$ & $0.3 \%$ \\
\hline
\end{tabular}

Cells synchronized by serum starvation were cultured for $24 \mathrm{~h}$ at $33^{\circ} \mathrm{C}$ and $37^{\circ} \mathrm{C}$, fixed, stained with $\mathrm{PI}$ and analyzed for DNA content on a flow cytometer ( see MATERIALS AND METHODS).

confluent cells were incubated at $37^{\circ} \mathrm{C}$ for $24 \mathrm{~h}$, morphology dramatically changed. Adherent cells exhibited a broader morphology and abundant floating spherical cells appeared (Fig. 2B).

\section{Growth properties at $37^{\circ} \mathrm{C}$}

Based on the hawksbill turtle cells characteristic growth inhibition and morphology at $37^{\circ} \mathrm{C}$, subsequent experiments were aimed at investigating the growth properties in more detail.

To investigate the cell cycle pattern during the growth inhibition state, cell numbers in the different phases of the cell cycle, at $33^{\circ} \mathrm{C}$ (normal growth temperature) and $37^{\circ} \mathrm{C}$ (growth inhibiting temperature) after synchronization by serum starvation, were measured by flow cytometry. The DNA histogram of cells immediately after serum starvation was characterized by synchronization in $\mathrm{G}_{0} / \mathrm{G}_{1}$ phase in $92.4 \%$ of cells. When incubated in growth medium at $33^{\circ} \mathrm{C}$ for $24 \mathrm{~h}$, cells evidently entered the cell cycle $\left(\mathrm{G}_{0} / \mathrm{G}_{1}\right.$ phase; $39.2 \%$, S phase; $46.6 \%, \mathrm{G}_{2} / \mathrm{M}$ phase; $14.2 \%$ ). Conversely, when the temperature was raised to $37^{\circ} \mathrm{C}$, the majority of cells remained arrested in the $\mathrm{G}_{0} / \mathrm{G}_{1}$ phase even after $24 \mathrm{~h}$ $(77.6 \%)$ (Table 1$)$. These results strongly suggest that hawksbill turtle cell growth is inhibited at $37^{\circ} \mathrm{C}$.

Since incubation at $37^{\circ} \mathrm{C}$ inhibited cell growth, we next investigated whether growth ability could be restored. After inhibition of cell growth by incubation at $37^{\circ} \mathrm{C}$ for $48 \mathrm{~h}$, cells were incubated at $33^{\circ} \mathrm{C}$. Consequently, cell growth was gradually restored and eventually approached control levels (Fig. 3). These results indicate cell growth inhibition at $37^{\circ} \mathrm{C}$ was a temporary and reversible event, and not affected the rate of exponentially growth phase.

\section{Detection of hsp70}

To determine whether the level of hsp expression changes in newly established turtle cells, total protein prepared from normal growth and growth inhibition state cells, was separated by SDS-PAGE and cross-reactivity of hsp70 was determined by immunoblotting. Figure 4 shows that anti-hsp72/hsc73 and anti-hsc73 antibodies specifically recognized respective proteins, and these protein levels increased at $37^{\circ} \mathrm{C}$. Chang et al. (2000) reported that available hsp72 antibody failed to bind to the turtle tissue proteins. Our results show that hsp70 (hsp72/hsc73 or hsc73) expressed in the hawksbill turtle cells at $37^{\circ} \mathrm{C}$ might correspond to heat-inducible hsp72 in human embryo cells. These results indicate that hawksbill turtle cells express low levels of heat-responsible hsp70.

The amount of hsp70, determined during elevating cul- 


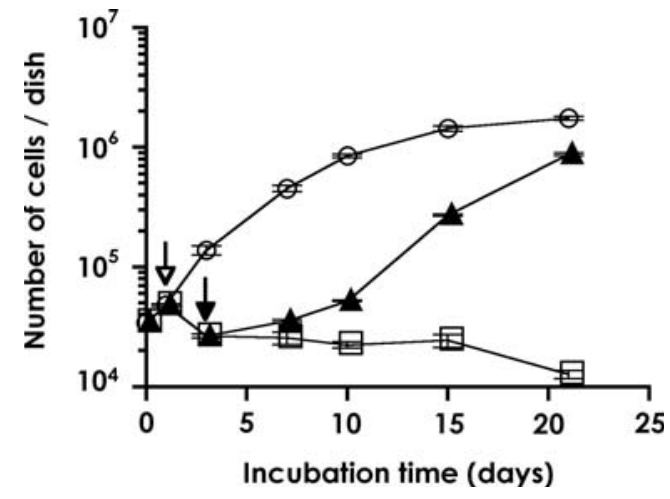

Fig. 3. Growth restoration of hawksbill turtle cells. Cells were plated at $2.5 \times 10^{4}$ cells $/ 35 \mathrm{~mm}$ culture dish in DMEM/10\% FBS and incubated at $33^{\circ} \mathrm{C}$ for $24 \mathrm{~h}$. Cells were divided into three groups: incubation at $33^{\circ} \mathrm{C}(\bigcirc), 37^{\circ} \mathrm{C}(\square)$ for up to 21 days (open arrow in the figure), and post-incubation at $33^{\circ} \mathrm{C}$ after incubation at $37^{\circ} \mathrm{C}$ for $48 \mathrm{~h}(\boldsymbol{\Delta}$, closed arrow in the figure). The medium was changed twice weekly. The curve was determined by counting cells using a hemocytometer. For each time point the mean and standard error of the mean are plotted $(n=3)$. Each experiment was performed in triplicate.

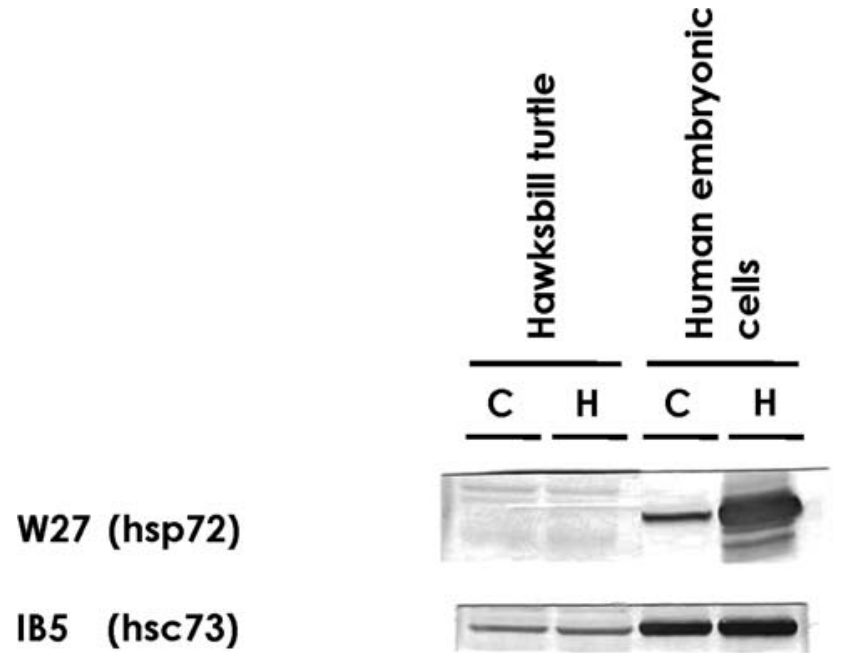

\section{N27F (hsp72/hsc73)}

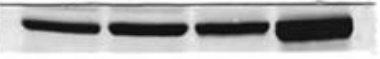

\section{A5 (hsp72/hsc73)}

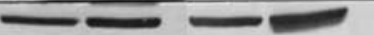

Fig. 4. Cross-reactivity of various anti-hsp70 antibodies to intracellular protein of hawksbill turtle cells. Fifteen micrograms of protein per lane was loaded for electrophoresis in SDS-PAGE. The crossreactivity of various anti-hsp70 antibodies was analyzed by western blotting. C, control; $\mathrm{H}$, hawksbill turtle cells incubated at $37^{\circ} \mathrm{C}$ for 72 $\mathrm{h}$, human embryo cells heated at $43^{\circ} \mathrm{C}$ for $10 \mathrm{~h}$.

ture temperature conditions, was increased in relation to cell growth. The relative amount of hsp70 and the reciprocal of the growth rate were plotted against absolute temperature. Figure 5 shows that increased growth rate leads to a parallel increase in relative amount of hsp70, within the range of growth permitting temperatures for hawksbill turtle cells.

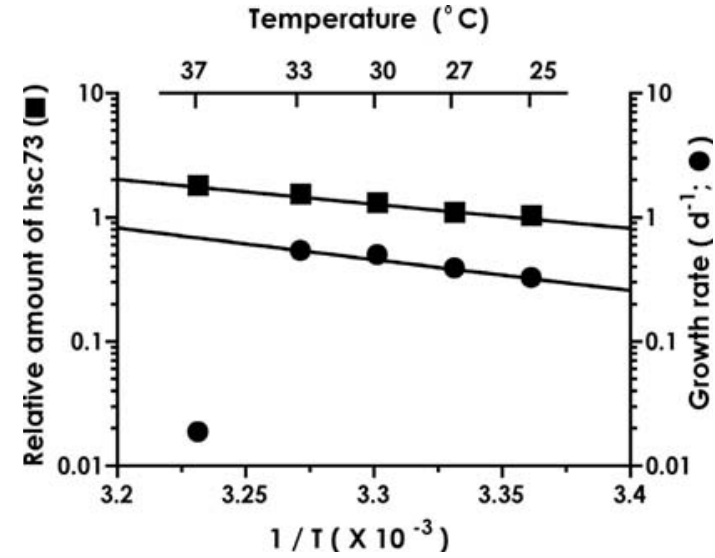

Fig. 5. Arrhenius plots of the growth rate and the relative amount of hsp70 of hawksbill turtle cells against culture temperature. The growth rate (O) was obtained from the slope of the exponential growth phase in Fig. 1. The amount of hsp70 (ם) was analyzed in 7day-old cultured cells at each temperature by western blotting. Lines were drawn by the method of least squares.

\section{DISCUSSION}

This is the first study to report the successful culture of embryonic hawksbill turtle cells and to demonstrate they differ in terms of thermal influence compared to mammalian cells. Hawksbill turtle cells were sub-cultured more than 50 times using a 1:4-split culture protocol and were optimally maintained at $33^{\circ} \mathrm{C}$. At low temperature $\left(19^{\circ} \mathrm{C}\right)$, cells were unable to replicate (data not shown). Koment and Haines (1982) reported that normal epithelioid skin cells of the green sea turtle, Chelonia mydas, were successfully grown at $30^{\circ} \mathrm{C}$, although replication occurred between 16 and $37^{\circ} \mathrm{C}$. At $37^{\circ} \mathrm{C}$ however, the cells were noticeably ragged and granulated, resulting from acceleration of metabolism by rapid change in pH. Lu et al. (1999) also reported that cells from C. mydas with fibropapillomas, exhibited optimal growth at $30^{\circ} \mathrm{C}$ and were able to proliferate at incubation temperatures between 20 and $25^{\circ} \mathrm{C}$. However cell growth was not observed when cultures were incubated at $37^{\circ} \mathrm{C}$ or $15^{\circ} \mathrm{C}$. E. imbricata nesting areas are located at lower latitudes compared with C. mydas (Uchida, 1982). The individual differences in permissible low culture temperature for cells from these two sea turtle species may reflect their respective habitats.

Hawksbill turtle cell growth was found to be completely inhibited when culture temperature rose from 33 to $37^{\circ} \mathrm{C}$ (Fig. 1). At this temperature, cells went through morphological changes, with increased numbers of floating cells and increased numbers in $G_{1}$ arrest (Fig. 2, Table 1). In addition, appearance of retained the progression between $S$ and $G_{2} / M$ phase may cause inhibition of DNA synthesis after incubation at $37^{\circ} \mathrm{C}$. Wang et al. (1989) reported that ovarian cells of the warm water Tilapia ceased to proliferate when moved from normal growth temperature of 31 to $37^{\circ} \mathrm{C}$, and became arrested in $G_{1}$ and $G_{2}$ phases of the cell cycle. Moreover, the ability of the arrested cells to re-enter the cell cycle when restored to a temperature of $31^{\circ} \mathrm{C}$ is likely attributable to the presence of certain proteins that fulfill the serum require- 
ments.

When culturing hawksbill cells at $37^{\circ} \mathrm{C}$, there was no further increase in the number of floating cells and attached cells after $24 \mathrm{~h}$. Although cells attaching on the surface of the culture dish were no growth at $37^{\circ} \mathrm{C}$, they were grown to a slight extent by changing the incubation temperature to $30^{\circ} \mathrm{C}$. Furthermore, floating cells were able to resume growth under normal culture conditions (data not shown), indicating that cells detaching from the surface of the culture dish were in a growth inhibition state and retained their cellular proliferation potential. Hence hawksbill turtle cells had temporally growth inhibition, but not gained heat resistance at $37^{\circ} \mathrm{C}$. As expected, cell growth hindered by slight heatstress was restored by transferring the cultures to normal growth conditions (Fig. 3). A similar phenomenon was reported by Bols et al. (1990) using reptilian IgH-2 cells from Iguana iguana. These cells are routinely grown at $36^{\circ} \mathrm{C}$, but at temperatures above $42^{\circ} \mathrm{C}$ cytoplasmic vacuoles appeared, cell bodies rounded with extended cell processes, shriveling became apparent, and cells eventually detached from the growth surface. Return of these cells to $36^{\circ} \mathrm{C}$ for 24 $\mathrm{h}$ enabled a variable portion to recover to their normal attachment potential and morphology.

Numerous studies on hsps have been published. In all organisms, the induction of hsps is remarkably rapid and intense, keeping with the notion that this is an emergency response. Moreover, there is a striking relationship between the induction temperature and the organism's environment (Lindquist, 1986; Lindquist and Craig, 1988; Maio, 1995). Bols et al. (1992) reviewed the use of fish cell cultures to study three temperature phenomena, including hsp synthesis, temperature acclimation and heat resistance. In the RTG-2 cell line from rainbow trout, a cause and effect relationship between the synthesis of the major hsps and the development of thermotolerance is suggested (Mosser and Bols, 1988). In reptiles, several in vivo studies relating to hsps have been reported to date. Hsp68 is the major component of the heat shock response in lizards and this protein is constitutively synthesized at high levels at normal temperature in thermophylic lizards (Ulmasov et al., 1992). In comparison the constitutive hsp70 is present in tissue homogenates from the red-eared slider, Trachemys scripta (Yu et al., 1994). Chang et al. (2000) have quantified hsp60 and hsp72/73 in myocardial tissue from two turtle species, the western painted turtle (Chrysemys picta belli, anoxia-tolerant) and the softshell turtle (Trionyx sponifer, anoxia-sensitive), during normoxia and anoxia. Ramaglia and Buck (2004) also reported that hsp72, hsp73 and hsp90 expression increases in $C$. picta belli during a forced dive. One unique report demonstrated that bacterial infection causes a tissuespecific increase in the expression of hsp73, hsp72 and hsp90 in C. picta belli (Ramaglia et al., 2004). In a reptilian cell line from Iguana iguana, synthesis of hsps comprising polypeptides of $87,76,70,29,28,22$, and $21 \mathrm{kDa}$ were identified (Bols et al., 1990).

In this report, we demonstrate for the first time that hsp70 exists in cultured hawksbill cells. Furthermore, increased levels of hsp70 were detected in these cells after exposure to slight heat-stress (at $37^{\circ} \mathrm{C}$ ). Ulmasov et al. (1992) reported that elevated levels of hsp70-like proteins, found in cells of thermophilic species at normal temperature, likely represent one adaptive mechanism. In addition, they reported a strong positive correlation between the content of hsp70-like proteins in nine lizard species under normal, nonheat-shock conditions and average temperature of each animal's ecological niche. This finding is consistent with the data presented in this study. Replication of hawksbill cells occurred between 25 to $33^{\circ} \mathrm{C}$ and the level of hsp70 expression increased, dependent on elevating culture temperature. Furthermore, the data demonstrate a significant positive correlation between the ability to proliferate and the level of hsp70 expression under normal growth conditions (correlation coefficient; $r^{2}=0.977$ ), although the level of hsp70 expression also increased at $37^{\circ} \mathrm{C}$. Human embryonic cell proliferation is completely inhibited at $43^{\circ} \mathrm{C}$, however it is able to restore by changing the incubation temperature back to $37^{\circ} \mathrm{C}$. In this case, the main factor inhibiting cell proliferation is denaturation of some cellular proteins; hsp is induced to repair denatured proteins. The same mechanism may occur in hawksbill turtle cells. Interestingly, increase of hsp70 expression promote cell proliferation at allowable temperature, alternative to that induced at unallowable temperature (Suzuki and Watanabe, 1994). This slight heatstress may positively regulate proliferation of hawksbill cells, although the exact mechanism remains elusive.

Conservation concerns for the critically endangered hawksbill turtles are immense because populations are severely reduced in every ocean basin (Bowen et al., 2007). An effective conservation strategy depends on understanding key aspects of hawksbill turtle biology, including the degree of isolation among nesting colonies, migratory pathways of juveniles and adults and the source for foraging populations. Corresponding conservation investigations have been reported. Park et al. (2003) found that a variety of hatchling sex ratios can be produced by hawksbills depending on the location and timing of nesting. Sea turtles, similar to many reptiles, possess temperature-dependent sex determination (Bull, 1980; Raynaud and Pieau, 1985; Standora and Spotila, 1985; Dournon et al., 1990; Janzen and Paukstis, 1991; Pieau et al., 1994; Pieau et al., 1999). Lin et al. (2008) indicate that newly developed microsatellites will facilitate the study of genetic diversity, population structure and species relationship of the hawksbill and other marine turtle species. Velez-Zuazo et al. (2008) carried out the largest focal genetic study of hawksbill turtle aggregation and were the first to examine mitochondrial DNA haplotype differences among different life-history stages and demographic segments, and across consecutive breeding seasons. However, these were all demonstrated in the absence of direct investigations using hawksbill cells.

In summary, we established hawksbill cell cultures and elucidated a number of their cellular properties influenced by culture temperature. Our newly established cell line will facilitate future studies to provide both information and conservation. As advocated by Bowen et al. (2007), like many marine conservation issues, international cooperation is the last and best hope for ensuring the hawksbills survival.

\section{ACKNOWLEDGMENTS}

We are grateful to Okinawa Prefecture for permitting the capture of hawksbill sea turtles. We also thank Okinawa Commemorative National Government Park for providing us with research materials. 
We would like thank Dr. Fusakazu Misoka (Industrial Technology Center of Nagasaki) for his helpful suggestions and Ms. Mayumi Kotani (Sunstar Inc.) for her assistance with flow cytometric analysis. We wish to thank Prof. Futoshi Aranishi (Shimane University) for his help with the manuscript. This work was supported by a grant for the Regional Links Research Program at the Nagasaki of Japan Science and Technology Corporation. The experiments reported herein comply with current Japanese law.

\section{REFERENCES}

Bols NC, Steels GB, Mosser DD, Heikkila JJ (1990) Heat resistance and heat-shock protein synthesis in a reptilian cell line, $\operatorname{lgH}-2$, from Iguana iguana. J Therm Biol 15: 163-170

Bols NC, Mosser DD, Steels GB (1992) Temperature studies and recent advances with fish cells in vitro. Comp Biochem Physiol 103A: $1-14$

Bowen BW, Grant WS, Hillis-Starr Z, Shaver DJ, Bjorndal KA, Bolten AB, Bass AL (2007) Mixed-stock analysis reveals the migrations of juvenile hawksbill turtles (Eretmochelys imbricate) in the Caribbean Sea. Mol Ecol 16: 49-60

Bull JJ (1980) Sex determination in reptiles. Q Rev Biol 55: 3-21

Chang J, Knowlton AA, Wasser JS (2000) Expression of heat shock proteins in turtle and mammal hearts: relationship to anoxia tolerance. Am J Physiol Regulatory Integrative Comp Physiol 278: R209-R214

Clark HF, Karzon DT (1967) Terrapene heart (TH-1), a continuous cell line from the heart of the box turtle Terrapene carolina. Exp Cell Res 48: 263-268

Clark HF, Cohen MM, Karzon DT (1970) Characterization of reptilian cell lines established at incubation temperatures of 23 to 36 degrees. Proc Soc Exp Biol Med 133: 1039-1047

Deeming DC, Ferguson MWJ (1988) Environmental regulation of sex determination in reptiles. Phil Trans R Soc Lond B 322: 19-39

Dournon C, Houillon C, Pieau C (1990) Temperature sex-reversal in amphibians and reptiles. Int J Dev Biol 34: 81-92

Harry JL, Williams KL, Briscoe DA (1990) Sex determination in loggerhead turtles: differential expression of two hnRNP proteins. Development 109: 305-312

Huang CC, Clark HF (1967) Chromosome changes in cell lines of the box turtle (Terrapene Carolina) grown at two different temperatures. Can J Genet Cytol 9: 449-461

Janzen FJ, Paukstis GL (1991) Environmental sex determination in reptiles: ecology, evolution, and experimental design. $Q$ Rev Biol 66: 149-179

Koment RW, Haines H (1982) Characterization of a reptilian epitheliloid skin cell line derived from the green sea turtle, Chelonia mydas. In Vitro 18: 227-232

Laemmli UK (1970) Cleavage of structural proteins during the assembly of the head of bacteriophage T4. Nature 227: 680685

Lin G, Chang A, Yap HW, Yue GH (2008) Characterization and cross-species amplification of microsatellites from the endangered Hawksbill turtle (Eretmochelys imbricate). Conserv Genet 9: 1071-1073

Lindquist S (1986) The heat-shock response. Annu Rev Biochem 55: 1151-1191

Lindquist S, Craig EA (1988) The heat-shock proteins. Annu Rev Genet 22: 631-677

Lu Y, Nerurkar VR, Aguirre AA, Work TM, Balazs GH (1999) Establishment and characterization of 13 cell lines from a green turtle (Chelonia mydas) with fibropapillomas. In Vitro Cell Dev Biol Animal 35: 389-393

Maio AD (1995) The heat-shock response. New Horiz 3: 198-207
Mansell JL, Jacobson ER, Gaskin JM (1989) Initiation and ultrastructure of a reptilian fibroblast cell line obtained from cutaneous fibropapillomas of the green turtle, Chelonia mydas. In Vitro Cell Dev Biol 25: 1062-1064

Marshall OJ, Harley VR (2001) Identification of an interaction between SOX9 and HSP70. FEBS Lett 496: 75-80

Mortimer JA, Meylan PA, Donnelly M (2007) Whose turtles are they, anyway? Mol Ecol 16: 17-18

Mosser DD, Bols NC (1988) Relationship between heat-shock protein synthesis and thermotolerance in rainbow trout fibroblasts. J Comp Physiol B 158: 457-467

Park A, Mortimer JA, Wibbels T (2003) Evaluation of incubation temperatures in hawksbill sea turtle nests on islands in the Republic of the Seychelles. Integr Comp Biol 43: 1024

Pieau C, Girondot M, Desvages G, Dorizzi M, Richard-Mercier N, Zaborski P (1994) Environmental control of gonadal differentiation. In "The Differences Between the Sexes" Ed by RV Short, E Balandan, Cambridge Univ Press, London/New York, pp 433448

Pieau C, Dorizzi M, Richard-Mercier N (1999) Temperature-dependent sex determination and gonadal differentiation in reptiles. Cell Mol Life Sci 55: 887-900

Ramaglia V, Buck LT (2004) Time-dependent expression of heat shock proteins 70 and 90 in tissues of the anoxic western painted turtle. J Exp Biol 207: 3775-3784

Ramaglia V, Harapa GM, White N, Buck LT (2004) Bacterial infection and tissue-specific Hsp72, -73 and -90 expression in western painted turtles. Comp Biochem Physiol Part C 138: 139-148

Raynaud A, Pieau C (1985) Embryonic development of the genital system. In "Biology of the Reptilia, Vol 15, Development B" Ed by C Gans, F Billett, Wiley, New York, pp 149-300

Standora EA, Spotila JR (1985) Temperature dependent sex determination in sea turtles. Copeia 3: 711-722

Suzuki K, Watanabe M (1994) Modulation of cell growth and mutation induction by introduction of the expression vector of human hsp70 gene. Exp Cell Res 215: 75-81

Uchida I (1982) Manual for the marine chelonology. Kaiyo to Seibutsu 23: 402-410 (in Japanese)

Ulmasov KA, Shammakov S, Karaev K, Evgen'ev MB (1992) Heat shock proteins and thermoresistance in lizards. Proc Natl Acad Sci USA 89: 1666-1670

Velez-Zuazo X, Ramos WD, van Dam RP, Diez CE, Abreu-Grobois A, Mcmillan WO (2008) Dispersal, recruitment and migratory behaviour in a hawksbill sea turtle aggregation. Mol Ecol 17: 839-853

Wang HC, Chen JD, Li GC, Yew FH (1989) Characterization of a heat-resistant strain of Tilapia ovary cells. J Cell Sci 92: 353359

Watanabe M, Suzuki M, Suzuki K, Nakano K, Watanabe K (1992) Effect of multiple irradiation with low doses of gamma-rays on morphological transformation and growth ability of human embryo cells in vitro. Int J Radiat Biol 62: 711-718

Yntema CL, Mrosovsky N (1980) Sexual differentiation in hatchling loggerheads (Caretta caretta) incubated at different controlled temperatures. Herpetologica 36: 33-36

Yntema CL, Mrosovsky N (1982) Critical periods and pivotal temperatures for sexual differentiation in loggerhead sea turtles. Can $J$ Zool 60: 1012-1016

Yu Z, Magee WE, Spotila JR (1994) Monoclonal antibody ELISA test indicates that large amounts of constitutive hsp-70 are present in salamanders, turtle and fish. J Therm Biol 19: 41-53

(Received July 8, 2013 / Accepted July 30, 2013) 